\title{
The Efficacy of Indigenous and Imported Predators Utilized in the Biological Control of Bemisia tabaci Biotype "B" (Homoptera: Aleyrodidae) in Greenhouse
}

\author{
S. ABD-RABOU \\ Plant Protection Research Institute, \\ Agricultural Research Center, Dokki-Giza, Egypt
}

\begin{abstract}
The silver leaf whitefly, Bemisia tabaci biotype "B" (Homoptera: Aleyrodidae) is one of the most serious vegetable and ornamental plants pest in Egypt. Predators play an important role in controlling this species.

The present work deals with the abundance of indigenous predators in greenhouse on three host plants mostly of vegetable crops during April-July, 1996. Chrysoperla carnea (Stephens) (Neuropteran: Chrysopidae) is considered the most abundant predator acting on Bemisia.

In the meantime, the work deals also with the potential of the imported predators, namely Delphastus pusillus Le Conte (Coleoptera: Coccinellidae) and Macrophillus caliginosus (Wagner) (Hemiptera : Miridae). These predators were released 3 times on eggplant (Solanum melongena) and at the ratio of 1 individual and 2 individuals/plant for D. pusillus and M. caliginosus, respectively. Results indicate that predators increased in numbers while whitefly population decreased in comparison to control homologues. Biotype B. tabaci was identified in John Innes Center, UK and recorded by Abd-Rabou (1999) in Egypt as first recorded for presence of this biotype.
\end{abstract}

Key words: Bemisia tabaci, predators of Bemisia, silver leaf whitefly.

The silver leaf whitefly, Bemisia tabaci biotype "B" (Homoptera: Aleyrodidae) is an important agricultural pest and transmitter of many economically important plant viruses.

Over 30 species of predators on B. tabaci (Genn.) belonging to the Chrysopidae, Coccinellidae, Miridae, Ceraphronidae and Phytoseiidae families have been recorded (De Barro, 1995). Generally, most predators are polyphagous feeders, however they are often capable of consuming large amounts of whiteflies (Gerling, 1990). Predators are considered as primary means of conserving naturally occurring entomophagous arthropods. Reduction in use of conventional pesticides is mainly targeted to conserve these arthropods (Nordlund and Legaspi, 1995).

Many species of the forementioned predators have the potential for controlling populations of Bemisia (eggs, nymphs and adults) under greenhouse and field conditions. Species utilized mainly for controlling the whitefly species of Bemisia in greenhouse and field crops are the coccinellids, Serangium paracesetosum (Sicard) (Kapadia and Puri, 1989), Hippodamia convergens (Guerin-Ménéville) (Hagler and Naranjo, 1994a, b), Delphastus pusillus (Le Conte) (Heinz et al., 1994). The chrysopids, Chrysoperla carnea (Stephens) and C. rufilabris (Burmeister) are efficient predators on protected crops (Ridgway and Murphy, 1984; Tulisalo, 1984) and the empidids, Drapetis subaenescens Collin and Tachidronia annulata (Fallen) play also an eminent role in control (Susman, 1988). 
The present work deals with the abundance of local predators of B. tabaci biotype "B". In the meantime, the work deals also with the potential of the imported predators namely, Macrophillus caliginosus (Wagner) (Hemiptera: Miridae) and Delphastus pusillus Le Conte (Coleoptera: Coccinellidae) for controlling this species of whiteflies on protected crops in Egypt.

\section{Materials and Methods}

The abundance of indigenous predators was carried out on tomato (Lycopersicum esculentum), cucumber (Cucumis sativus) and eggplant (Solanum melongena) plants infested with Bemisia tabaci Biotype "B" only and nothing else that infesting species. Due to the fact that greenhouses in which these plants are raised did not receive any chemical treatment thus this Biotype " $B$ " infestation percentage indicate that these individuals are attacked by predators and that these predators are abundant on these hosts.

The predators of $B$. tabaci Biotype "B" on each of these plants in three greenhouses were counted out in $10 \mathrm{~m}^{2}$ in each greenhouse at one week intervals during a period of four months (April-July, 1996). For assessing whiteflies in these plastic greenhouses, a sample of 15 leaves found in $1 \mathrm{~m}^{2}$ were picked. B. tabaci Biotype "B" was reared inside greenhouses on eggplants. Each eggplant in these greenhouses was kept in a plastic pot of $18 \times 15 \mathrm{~cm}$.

In a wooden cage of $70 \times 80 \times 110 \mathrm{~cm}, 120$ eggplant were transferred to a new greenhouse (no. of whiteflies was recorded on 15 leaves in treated and untreated), of these 120 pots, 20 pots were kept untreated to serve as control. While 100 pots were used for testing predation (control pots and treated pots were kept a part away). For each plant infested by $B$. tabaci, one imported predator namely $D$. pusillus was released to act on $B$. tabaci Biotype "B". Releases were repeated monthly at the same rate.

The same technique was followed in another new greenhouse for M. caliginosus. However, the acted on eggplant in case of this latter predator, amounted 320 of which 50 were kept as control. The former predator was tested during April-July 1996 at the rate of 1 predator/plant while the latter predator was tested during Sept.-Dec. 1997 at the rate of 2 predators/plant. Weekly counts of both predators (30 plant) and $\mathrm{B}$. tabaci biotype "B" stages (15 leaves) were recorded.

\section{Results and Discussion}

Abundance of indigenous predators of Bemisia tabaci biotype " $B$ ":

During the present study, seven species of predators were recorded from samples of $B$. tabaci biotype " $\mathrm{B}$ " in greenhouse on three plants. These are listed below in the following alphabetical order:

Campylomma nicolasi (Reuter) (Hemiptera: Miridae)

Chrysoperla carnea Stephens (Neuroptera: Chrysopidae) 
Coccinella septempunctata (L.) (Coleoptera: Coccinellidae)

Deraeocoris sp. (Hemiptera: Miridae)

Geocoris sp. (Hemiptera: Lygaeidae)

Orius sp. (Hemiptera: Anthocoridae)

Scymnus syriacus (Marshall) (Coleoptera: Coccinellidae)

On tomato plants (L. esculentum), C. septempunctata are the most abundant predators attacking all stages of the forementioned type of Bemisia. The highest numbers recorded for this predator was 16 individuals $/ 10 \mathrm{~m}^{2}$ during the 7 th week (May 13th, 1996). C. carnea, Orius sp., S. syriacus were counted on tomato plants and were found attacking Bemisia at high rates that equivalent to per $10 \mathrm{~m}^{2}$ were 15,3 and 6 during 8 th, 3rd and 9th weeks, respectively. Applying multiple regression to the relation between whitefly numbers and associated predators revealed $\mathrm{R}^{2}$ value of $0.0486(\mathrm{P}>0.05)$. On cucumber plants (C. sativus), C. carnea was found to be the most abundant predator attacking Bemisia. The highest numbers recorded for this predator were 17 individuals $/ 10 \mathrm{~m}^{2}$ during 7th week. C. nicolasi, C. septempunctata, Geocoris sp. and Orius sp. were counted on cucumber plant acting on Bemisia were 3, 4, 7 during the 6th week/10 $\mathrm{m}^{2}$ compared to $12 / 10 \mathrm{~m}^{2}$ during the 4th week. Applying multiple regression to the relation between whitefly numbers and associated predators revealed $\mathrm{R}^{2}$ value of $0.6272(\mathrm{P}<0.05)$. Out of the five predators only $C$. nicolasi and $C$. carnea gave significant relation $(\mathrm{P}<0.05$ and $\mathrm{P}$ $<0.01$, respectively). Other three predators gave significant relation $(\mathrm{P}>0.05)$.

On eggplant ( $S$. melongena), $C$. carnea was the most abundant predator that attained numbers of $22 / 10 \mathrm{~m}^{2}$ during the 8 th week. C. septempunctata, Deraeocoris sp. and $S$. syriacus were counted on eggplant and reached the quantity of 18, 2 and 4 during the 7th, 6th and 6th weeks, respectively. Applying multiple regression to the relation between whitefly numbers and associated predators revealed $\mathrm{R}^{2}$ value of $0.7997(\mathrm{P}>$ 0.01). Out of the four predators, only $C$. carnea and $C$. septempunctata gave significant relation $(\mathrm{P}<0.01)$. Other two predators gave non-significant relation $(\mathrm{P}>0.05)$.

These result indicate that $C$. carnea is the most important predator in Egypt. Nordlund and Legaspi (1995) observed the important role of C. carnea in controlling Bemisia sp., C. septempunctata was found to be the second abundant species acting on Bemisia in Egypt as given in Fig. 1. This predator in Europe assumed as basis for supporting biological control of different insects. This is due to its polyphagous feeding habits (Schmuck et al., 1997). C. nicolasi and Deraeocoris sp. are recorded here as predators of the whitefly, B. tabaci Biotype "B". This is the first record in Egypt. The remaining species given in Fig. 1 were recorded on a small scale.

\section{Efficacy of imported predators Delphastus pusillus Le Conte}

Twenty-one days later than time of first releases of this predator, the number recorded/30 plants reached 22; meanwhile, the population of whiteflies attained a number of 415/15 leaves compared to 51/15 leaves in control experiments. At the time of second releases, the numbers of predators ranged between 13-17/30 plants, while the population of whiteflies was 377-213/15 leaves, compared to 785/15 leaves among controls. During 

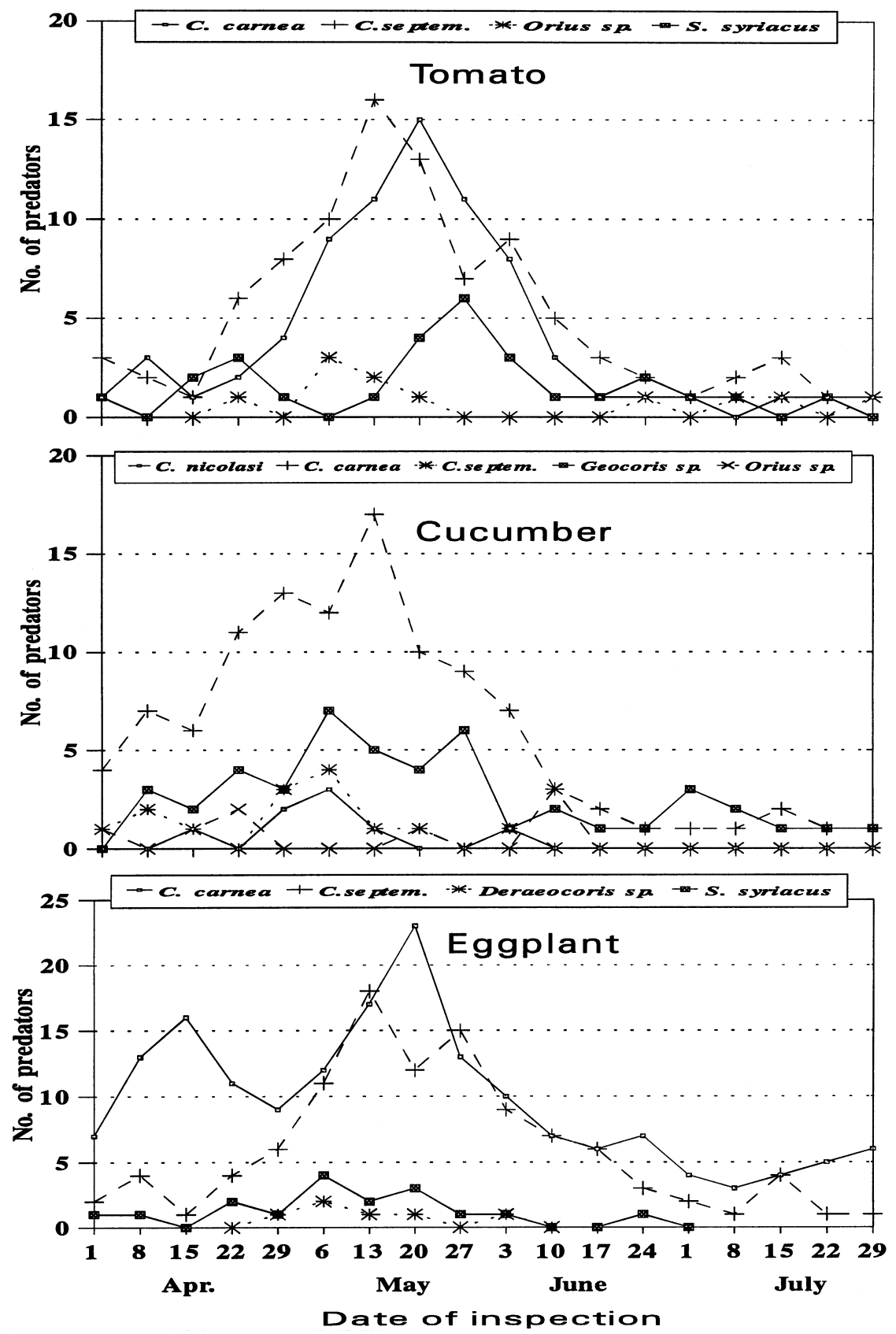

Fig. 1. Number of predators attacking B. tabaci biotype "B" on tomato, cucumber and eggplant plants 


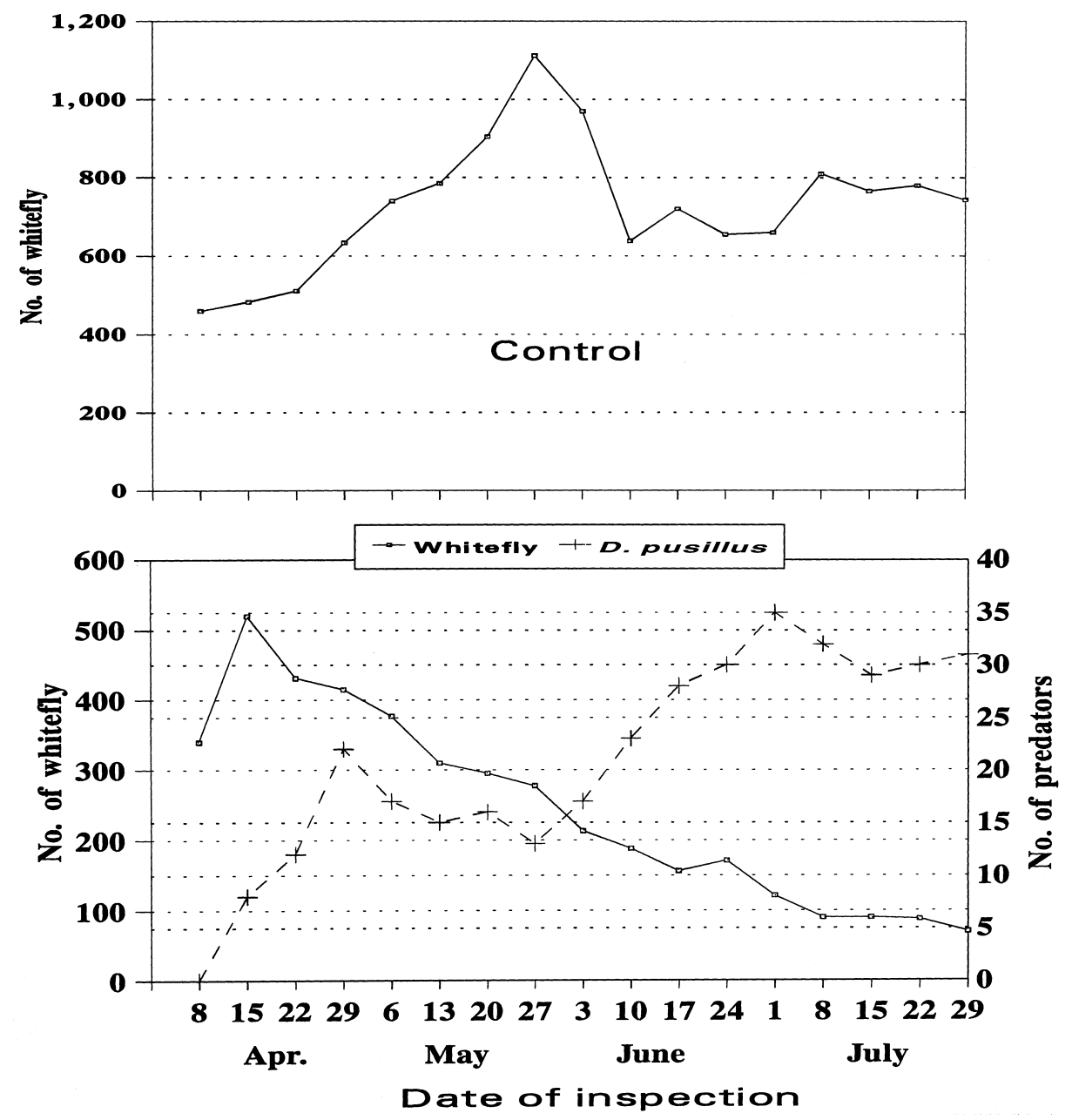

Fig. 2a. Number of predators D. pusillus and population of whiteflies in treatment and control

the 3rd release, the predators amounted $35 / 30$ plants, while the population of whiteflies amounted 121/15 leaves, compared to 638/15 leaves among controls (Fig. 2a).

These result indicate that $D$. pusillus increased, while the population of Bemisia consequently decreased. The population of whiteflies in control gradually increased during the period of the experiment.

De Barro (1995), Roltsch and Pickett (1994), Fransen (1994), Heinz et al. (1994), Heinz and Parrella (1994), Hoelmer et al. (1993 and 1994) who recorded D. pusillus has proven the ability of this predator to control Bemisia in greenhouse crops. 

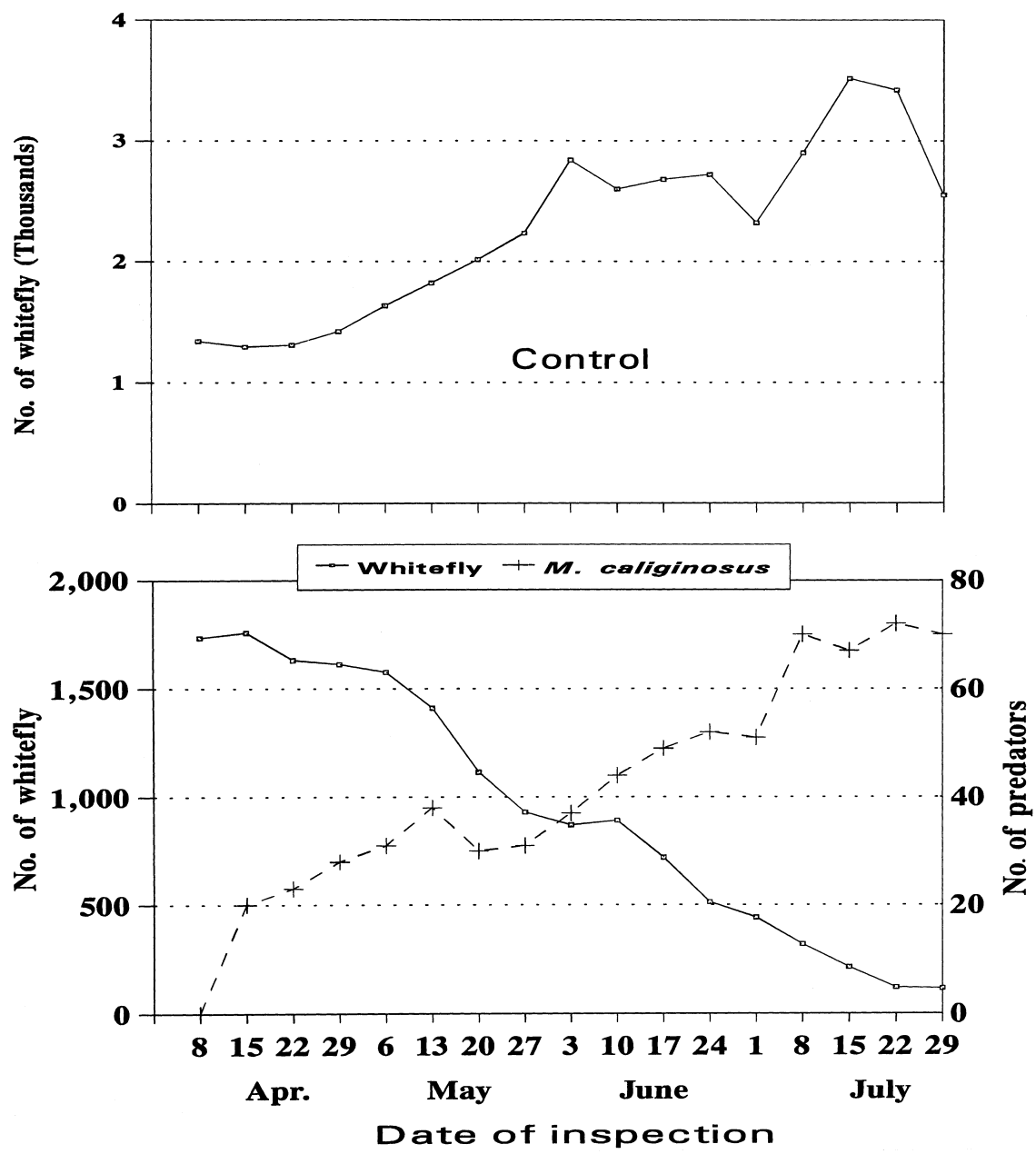

Fig. 2b. Number of predators $M$. caliginosus and population of whiteflies in treatment and control

\section{Macrophillus caliginosus (Wagner)}

One month later than time of first releases, the number of predator reached 31/30 plants, while population of whiteflies was 1576/15 leaves, compared to 1420/15 leaves among controls. The number of predator increased gradually after the second and third releases and reached 72/30 plants, while population of whiteflies was 215/15 leaves compared to 2720/15 leaves among controls (Fig. 2b).

These results indicate that $M$. caliginosus increased rapidly and the population of whiteflies decreased. Controversely, whitefly population among control increased.

These findings are in agreement with results obtained by Van Schelt (1994) and Fransen (1994). 


\section{Literature}

Abd-Rabou, S. (1999): New records on whiteflies in Egypt. Egypt. J. Agric. Res. 77, 1143-1146.

De Barro, P. (1995): Bemisia tabaci biotype "B": a review of its biology, distribution and control. CSIRO Australia, Tech. No. 36, pp. 58.

Fransen, J. J. (1994): Bemisia tabaci in the Netherlands, Here to Stay? Pesticide Science 42, 129-134.

Gerling, D. (1990): Natural enemies of whiteflies predators and parasitoids. In: Gerling, D., Whiteflies: their bionomics, pest status and management. Intercept Ltd., Andover Hants. pp. 147-185.

Hagler, J. R. and Naranjo, S. E. (1994a): Quantitative survey of two coleopteran predators of Bemisia tabaci (Homoptera: Aleyrodidae) and Pectinophora gossypiella (Lepidoptera: Gelechiidae) using a multiple prey gut control ELISA. Environmental Entomology 23, 193-197.

Hagler, J. R. and Naranjo, S. E. (1994b): Determining the frequency of heteropteran predation on sweetpotato whitefly and pink bollworm using multiple ELISA. Entomologia Experimentalis et Applicata 72, 59-66.

Heinz, K. M., Brazzle, J. R., Pickett, C. H., Natwick, E. T., Nelson, J. M. and Parrella, M. P. (1994): Delphastus pusillus as a potential biological control agent for sweetpotato (silver leaf) whitefly. California Agricultural 48, 35-40.

Heinz, K. M. and Parrella, M. P. (1994): Biological control of Bemisia argentifolii (Homoptera: Aleyrodidae) infesting Euphorbia pulcherrima: Evaluations of releases of Encarsia luteola (Hymenoptera: Aphelinidae) and Delpahstus pusillus (Coleoptera: Coccinellidae). Environmental Entomology 23, 1346-1353.

Hoelmer, K. A., Osbourne, L. S. and Yokomi, R. K. (1993): Reproduction and feeding behaviour of Delphastus pusillus (Coleoptera: Coccinellidae), a predator of Bemisia tabaci (Homoptera: Aleyrodidae). J. of Economic Entomology 86, 322-329.

Hoelmer, K. A., Osbourne, L. S., Bennett, F. D. and Yokomi, R. K. (1994): Biological control of sweetpotato whitefly in Florida. In: Rosen, D., Bennett, R. D., Capinera, J. I. (eds): Pest Management in the Subtropics: Biological control, a Florida Perspective. Intercept Press, Andover, UK. pp. 101-103.

Kapadia, M. N. and Puri, S. N. (1989): Seasonal incidence of natural enemies of Bemisia tabaci (Gennadius) on cotton. Indian J. Ecology 16, 164-168.

Nordlund, D. A. and Legaspi, J. C. (1995): Whitefly predators and their potential for use in biological control. In: Gerling, D. (ed.), Bemisia (1995): Taxonomy, Biology, Damage, Control and Management. Intercept Ltd., Andover Hants. pp. 499-513.

Ridgway, R. L. and Murphy, W. L. (1984): Biological control in the field. In: Canard, M., Séméria, Y. and New, T. R. (eds) Biology of Chrysopidae. W. Junk, Boston, pp. 220-228.

Roltsch, W. J. and Pickett, C. H. (1994): Areawide establishments of Delphastus pusillus a predator of silverleaf whitefly in the Imperial Valley. ARS-125, $147 \mathrm{pp}$.

Schmuck, R., Tornier, K. I., Bock, K. D., Waltersdorfer, A. and Kunast, Ch. (1997): A semi-field testing procedure using the ladybird beetle, Coccinella septempunctata L. (Col.: Coccinellidae), for assessing the effects of pesticides onnontarget leaf-dwelling insects under field exposure. Canadian J. Applied Entomology 121, 111-120.

Susman, I. (1988): The cotton insects of Israel and aspects of the biology of Detaecorus pattens Reuter (Heteroptera: Miridae). M. S. Thesis, Tel Aviv Univ., 154 pp. (English summary).

Tulisalo, U. (1984): Biological control in the greenhouse. In: Canard, Séméria, Y. and New, T. R. (eds) Biology of Chrysopidae. W. Junk, Boston, pp. 228-233,

Van Schelt, J. (1994): The use of Macrolophus caliginosus as a whitefly predator in protected crops. Bemisia Newsletter 8, 26 pp. 